Nr 2(65), 2020, s. 161-187

https://doi.org/10.12797/Politeja.17.2020.65.13

\author{
Aleksandra GRUSZCZYK (D) \\ aleksandra.gruszczyk@gmail.com
}

\title{
BABYKILLERS CZY OFIARY SYSTEMU?
}

\author{
WALKA O KSZTAŁT PAMIĘCI SPOŁECZNEJ \\ NA PRZYKŁADZIE AMERYKAŃSKIEGO \\ ZAANGAŻOWANIA W WOJNĘ W WIETNAMIE
}

ABSTRACT Babykillers or System Victims? Fight for the Shape of Social Memory on the Example of American Involvement in the Vietnam War

Social trauma is a result of a collusion between the individual experience of trauma and the culture-mediated process of communal creation, negotiation and structuring of meaning. It emerges from the process of communalisation of individual trauma: when individual trauma becomes an experience shared originally by a 'carrier group' and later on spreads throughout whole societies. As a communal experience trauma alienates from their carriers by means of cultural media and their products. In the form of cultural artifacts, such as movies or books, it transforms into a Durkheimian social fact. The inability to negate it ultimately forces the society to engage in negotiations of meaning, resulting in either a refutation or an inclusion of the carrier group's trauma into the wider social identity. The act of emergence of social trauma can be defined as a complex, multilayered process of continuous expansion of the intersubjective field. The history of American engagement in the Vietnam war and the society's reaction to it serves as an informative example of this process.

Keywords: post-memory, Vietnam war, PTSD, social trauma, social memory

Słowa kluczowe: postpamięć, wojna w Wietnamie, PTSD, trauma społeczna, pamięć społeczna 


\section{WOJNA W WIETNAMIE W AMERYKAŃSKIEJ PAMIĘCI SPOŁECZNEJ}

Zjawisko postpamięci w definicji Marianne Hirsch opisuje złożoną reakcję pokolenia dzieci na traumatyczne doświadczenia rodziców, przeżyte jeszcze przed ich narodzeniem, lecz przekazane im w postaci tak intensywnej i głębokiej, że mogą one sprawiać wrażenie ich własnych wspomnień ${ }^{1}$. Hirsch kładzie szczególny nacisk na bezpośrednią relację „dawców” i „biorców” postpamięci, podkreślając rolę fotografii w procesie przekazywania wspomnieńn ${ }^{2}$ Jednak, analizując postpamięć w szerszej perspektywie jako zjawisko transmisji szczególnej formy narracji o przeszłości, o znaczącym ładunku kognitywno-afektywnym, poprzez szereg dostępnych mediów, takich jak fotografia, film, książka, muzyka, publiczne wystąpienia itp., powinniśmy umieścić fenomen postpamięci w ramach procesów pamięci społecznej ${ }^{3}$. Wspomnienia jednostkowe, również te będące efektem procesów szeroko pojętej postpamięci, pozostają wszak we współzależnej relacji z pamięcią zbiorową - ramy pamięci społecznej wyznaczają dominujące spo-

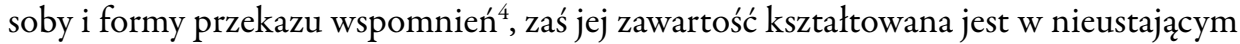
procesie społecznych negocjacji, akceptacji i odrzucenia wspomnień indywidualnych. Zjawisko traumy społecznej, rozumianej jako rana pamięci zbiorowej, pęknięcie wspólnotowej tożsamości tak głębokie i dotkliwe, że trwające w tej pamięci nawet stulecia po wystąpieniu traumatycznego wydarzenia, opisuje bardzo podobne mechanizmy jednak nie w skali jednostkowej, a w skali całych zbiorowości ${ }^{5}$. Kwestia jednostkowej „własności” wspomnień traci zatem istotność w sytuacji, kiedy pamięć o przeszłości ulega intersubiektywizacji i staje się elementem wspólnej tożsamości - rodziny, wspólnoty sąsiedzkiej, plemienia czy całych społeczeństw i narodów. Tak zdefiniowany proces

\section{Hirsch, The Generation of Postmemory, „Poetics Today” 2008, vol. 29, nr 1, s. 103-128.}

2 Taż, Family Frames. Photography, Narratives and Postmemory, Cambridge 1997.

3 Podobne problemy, choć z innej perspektywy, analizuje Alison Landsberg w książce Prosthetic Memory: The Transformation of American Remembrance in the Age of Mass Culture, New York 2004. W niniejszym artykule stosuję jednak koncepcję postpamięci Hirsch oraz teorię pamięci społecznej Halbwachsa. Z socjologicznego punktu widzenia koncepcja Landsberg nadmiernie upraszcza procesy interakcji pamięci jednostkowej i zbiorowej, a tworząc nadmiarowe kategorie, takie jak pamięć protetyczna, traktowana przez autorkę dosłownie, a nie metaforycznie, ostatecznie zaciemnia i tak niezwykle złożony obraz fenomenu pamięci kulturowej. Zainteresowanych krytyczną analizą podejścia Landsberg odsyłam do artykułów Jamesa Bergera i Caspera Tybjerga: J. Berger, Which Prosthetic? Mass media, Narrative, Empathy and Progressive Politics, „Rethinking History” 2007, vol. 11, nr 4, s. 597-612; C. Tybjerg, Refusing the Reality Pill: A Film Studies Perspective on Prosthetic Memory, Kosmorama, 10 III 2016, [online] https://www.kosmorama.org/en/kosmorama/artikler/refusing-reality-pill-film-studies-perspective-prosthetic-memory, 31 X 2019.

4 Maurice Halbwachs, prekursor analizy pamięci społecznej, uważał wręcz, że pamięć jednostkowa jest pochodną pamięci społecznej, jako że formy tej pierwszej zależne są od ram socjalizacji wyznaczanych przez tę drugą. M. Halbwachs, Spoteczne ramy pamięci, przeł. M. Król, Warszawa 2008.

5 Definicję traumy społecznej przyjmuję za Neilem Smelserem. N. Smelser, Psychological and Cultural Trauma, [w:] J.C. Alexander, R. Eyerman, B. Giesen, N.J. Smelser, P. Sztompka, Cultural Trauma and Collective Identity, Berkeley 2004. Por. A. Gruszczyk, Czarne światto. Analiza zjawiska powojennej traumy spotecznej w kulturze Stanów Zjednoczonych Ameryki, Kraków 2017. 
intersubiektywizacji traumy jest tematem niniejszego artykułu, który ukazuje przebieg konfliktu konkurujących ze sobą wizji pamięci społecznych dotyczących historii amerykańskiego zaangażowania w wojnę w Wietnamie.

Wojna ta, znana też jako druga wojna indochińska, stanowi doskonały przykład nie tylko procesu uwspólniania pewnego doświadczenia pokoleniowego, ale również niezwykle złożonego procesu uspołecznienia traumy. Proces ten polega na stopniowym upowszechnianiu się świadomości istnienia oraz treści szczególnego, traumatycznego doświadczenia grupy nosicielskiej jednostek w szerszej świadomości społecznej, a jego zakończenie - płynne i nieostateczne, jak wszystkie elementy życia społecznego można umieścić w momencie podjęcia społecznie usankcjonowanej decyzji o odrzuceniu lub akceptacji tej traumy jako elementu wspólnej tożsamości danej zbiorowości. W tym kontekście sama historia wietnamskiej wojny, rozumiana jako forma narracji o przeszłości, stanowi ilustrację procesu zbiorowej negocjacji znaczeń, a sposób i treść jej publicznej oceny oraz opisu do dziś bywa znaczącą deklaracją wyznawanych ideologii, postaw poznawczych i przekonań społeczno-politycznych zarówno jednostek, jak i całych grup.

Mimo że walki na terytorium dawnych francuskich Indochin trwały od końca drugiej wojny światowej, mianem wojny w Wietnamie określa się zazwyczaj okres amerykańskiego udziału w konflikcie, trwający, według różnych szacunków, od dwudziestu do dwudziestu pięciu lat. Historycy nadal spierają się nie tylko o ocenę przebiegu i rezultatów tego konfliktu, ale nawet o precyzyjne określenie czasu jego trwania. O ile bowiem data zakończenia wojny, wyznaczana upadkiem Sài Gòn 30 kwietnia 1975 roku, nie budzi kontrowersji, o tyle jej potencjalnych początków jest wiele. Najczęściej przyjmowaną datą jest 1 listopada 1955 roku, kiedy Amerykanie, w obawie przed wzmocnieniem wplywów ZSRR w regionie, utworzyli grupę doradczą MAAG Vietnam (Military Assistance Advisory Group), wyodrębniając ją z istniejącej wcześniej MAAG Indochina. Amerykańska decyzja była reakcją na porażkę Francji, aktywnie wspieranej przez Stany Zjednoczone w pierwszej wojnie indochińskiej ${ }^{6}$. Na mocy ustaleń genewskiej konferencji pokojowej z 1954 roku Wietnam oficjalnie uzyskał niepodległość i został podzielony na część północną i południową, a Francja zadecydowała o całkowitym opuszczeniu terytorium byłej kolonii. USA poparły wówczas władze Wietnamu Południowego, jednocześnie otwierając nowy front zimnowojennych zmagań z blokiem wschodnim pod wodzą ZSRR, który wspierał zjednoczeniowe ambicje komunistycznego Wietnamu Północnego. Natomiast w perspektywie pamięci zbiorowej ramy wojny $\mathrm{w}$ Wietnamie symbolicznie wyznaczają daty zapisane na znajdującym się w Waszyngtonie pomniku ku czci poległych - Vietnam Veterans Memorial. Kalendarium udokumentowanych śmierci rozpoczyna się 8 czerwca 1956 roku, dniem zabójstwa Richarda B. Fitzgibbona, kończy zaś na 15 maja 1975 roku,

6 P.B. Davidson, Vietnam at War. The History 1946-1975, Oxford 1991, s. 167-168. W 1953 roku Stany wysłały na terytorium zbuntowanych francuskich kolonii specjalny wojskowy zespół doradczy pod dowództwem Johna O’Daniela, który miał ocenić zasadność udzielenia pomocy Francji. W 1954 roku USA zagwarantowały Francji wielusetmilionową pożyczkę na wzmocnienie działań ofensywnych na terenie Wietnamu. 
dacie upamiętniającej śmierć Keltona Reny Turnera w ostatniej oficjalnej bitwie tej wojny, znanej jako incydent Mayaguez ${ }^{7}$.

Okres zimnej wojny, wymagającej subtelności w działaniach politycznych i wojskowych, szczególnie tych prowadzących do przesunięć w strefach wpływów obu bloków, nie sprzyjał jednoznaczności i śmiałym deklaracjom. Trudno więc się dziwić, że Stany Zjednoczone otwarcie - choć nieformalnie - przystąpily do wojny w Wietnamie dopiero w sierpniu 1964 roku, po kontrowersyjnym incydencie militarnym w Zatoce Tonkińskiej, kiedy to Kongres USA uchwalił Gulf of Tonkin Resolution. Dokument ten nadawał prezydentowi USA szerokie uprawnienia wojskowe, w tym możliwość podejmowania decyzji o użyciu konwencjonalnych sił zbrojnych poza granicami kraju. Lyndon B. Johnson wykorzystał nowo nabyte prerogatywy, rozpoczynając akcję szeroko zakrojonych lotów rozpoznawczych i nalotów bombowych, a następnie wysyłając do Wietnamu oddziały wojsk lądowych. W szczytowym okresie, w czasie ofensywy Tet w 1968 roku, liczba amerykańskich żołnierzy w Wietnamie wynosiła niemal 540 tys. ${ }^{8}$

Wojna w Wietnamie okazała się najdroższym i najkrwawszym starciem zimnej wojny, nieodwołalnie przekształcając stosunki międzynarodowe w Azji i międzymocarstwową równowagę tamtego okresu, ale również w dramatyczny sposób wpływając na społeczną tożsamość Amerykanów. Cały konflikt pochłonął, wedle różnych szacunków, około $2 \mathrm{mln}$ ofiar, w tym prawdopodobnie około $1,1 \mathrm{mln}$ członków Viet Congu i 250 tys. żołnierzy Wietnamu Południowego oraz 58220 żołnierzy amerykańskich?. USA tylko w ostatniej dekadzie wojny w Wietnamie wydały na cele militarne z nią związane 111 mld dolarów ${ }^{10}$, zaś na bezpośrednią pomoc ekonomiczną dla Wietnamu Południowego - 28,5 mld dolarów. Jednak twarde dane ekonomiczne czy demograficzne nie tworzą pełnego obrazu wojny - znacznie istotniejsze dla zrozumienia wagi tego konfliktu we wspólnej pamięci i tożsamości Amerykanów są koszty społeczne, również te niepoliczalne żadną dostępną miarą.

\section{WOJNA „NA WYCIĄGNIĘCIE RĘKI”}

Wietnamski konflikt charakteryzował się kilkoma unikalnymi cechami, z których dla sfery zbiorowych wyobrażeń amerykańskiego społeczeństwa najbardziej znaczące okazały się: niemal całkowity brak cenzury w przekazywaniu wiadomości z frontu połączony ze zbiorową koncentracją, czy wręcz fiksacją na teraźniejszości, oraz powszechny pobór wojskowy i związana z nim loteria poborowa. Współwystępowanie tych dwóch

Starcie między oddziałami USA a Czerwonymi Khmerami z 12-15 maja 1975 roku, w którym zginęto piętnastu amerykańskich żołnierzy. Kelton Rena Turner jest ostatnią potwierdzoną ofiarą (KIA Killed In Action); Gary L. Hall, Joseph N. Hargrove i Danny G. Marshall zostali uznani za zaginionych (MIA - Missing In Action), a ich ciał nigdy nie odnaleziono. Por. http://www.thewall-usa.com/ names.asp, 13 VIII 2018.

8 P.B. Davidson, Vietnam at War..., s. 565.

9 N.F. DeBruyne, American War and Military Operations Casualties: Lists and Statistics, Congressional Research Service, 2017, [online] https://fas.org/sgp/crs/natsec/RL32492.pdf, 13 VIII 2018.

10 Ekwiwalent 738 mld dolarów w przeliczeniu na siłę nabywczą pieniądza na rok 2011. 
zjawisk poskutkowało nieprzerwaną obecnością wojny w niemal każdym domu. Dla ówczesnych Amerykanów była ona czymś realnym, namacalnym, dostępnym w każdej chwili, w najdrobniejszym, najbardziej brutalnym i krwawym szczególe. Istniała w nieustającym „tu i teraz", a sposób jej transmisji, nasycony pobudzającymi wyobraźnię obrazami i narracyjną strukturą, w wysokim stopniu angażował odbiorców, wzbudzając w nich zróżnicowane reakcje. Ze względu zaś na obowiązujące prawo powszechnego poboru była jednocześnie faktem niezwykle istotnym i decydującym o przyszłości milionów jednostek i ich rodzin. Tylko w latach 1964-1975 służbę wojskową w południowo-wschodniej Azji odbyło prawie 3,5 mln obywateli USA.

Pamiętnych momentów w tej „utelewizyjnionej wojnie”, jak nazywa ją Daniel C. Hallin ${ }^{11}$, było wiele: od reportażu CBS w 1965 roku, w którym pokazano, jak Marines zapalniczkami Zippo podpalają chaty w wiosce Cam Ne, poprzez słynne wystąpienie Waltera Cronkite'a, który po pobycie w Wietnamie publicznie zakwestionował oficjalną narrację amerykańskiego zwycięstwa w ofensywie Tet, aż po publikację tajnych Pentagon Papers przez „The New York Times” i „The Washington Post” w 1971 roku. Liczne szokujące i poruszające zdjęcia, dokumentujące z bliska wydarzenia wojny w Wietnamie, nie tylko przybliżały skalę i brutalność konfliktu zwykłym Amerykanom, ale wręcz zyskały status historycznych symboli, znanych niemal każdemu obywatelowi USA przynależącemu do określonych pokoleń. Milcząca wymowność tych obrazów, wynikająca $\mathrm{z}$ naturalnej dla medium fotograficznego zdolności do pobudzenia emocji i wyobraźni, emblematycznego charakteru zdjęć, łatwości ich rozpowszechniania oraz podatności na manipulację odbiorem poprzez manipulację kontekstem, w jakim były ukazywane, uczyniła z nich sztandarowe narzędzie wpływu w procesach negocjowania treści amerykańskiej pamięci społecznej. Wojna w Wietnamie została w dużej mierze zapamiętana przez amerykańskie społeczeństwo poprzez obrazy właśnie - nieretuszowane, nieocenzurowane zdjęcia tak z frontu, jak i z kraju, reportaże telewizyjne czy wreszcie filmy fabularne, prezentujące zarówno wydarzenia historyczne, takie jak bitwy o Hamburger Hill czy Ia Đrăng, jak i fikcyjną narrację, ekranizacje wspomnień weteranów czy nawet alegoryczny obraz wojny jako takiej.

W połączeniu z szeregiem innych czynników, w tym również wewnętrznych, takich jak znaczące upolitycznienie życia publicznego i pojawienie się głębokich podziałów ideologicznych w amerykańskim społeczeństwie, zjawiska kulturowe wpłynęły w istotnym stopniu na ukształtowanie społecznego obrazu wojny wietnamskiej. O ile w 1965 roku 60\% badanych w sondażu Gallupa uważało, że wysłanie amerykańskich wojsk do Wietnamu było posunięciem słusznym, a tylko $24 \%$ uznawało tę decyzję za błędną, o tyle w 1973 roku stosunek amerykańskiego społeczeństwa do udziału w II wojnie indochińskiej uległ kompletnemu odwróceniu: 60\% badanych wyrażało sprzeciw, a 29\% popierało decyzję o wysłaniu wojsk ${ }^{12}$.

11 „Televised war”. D.C. Hallin, The „Uncensored War”: The Media and Vietnam, Berkeley-Los Angeles 1989.

12 F. Newport, J. Carroll, Iraq Versus Vietnam: A Comparison of Public Opinion, Gallup News Service, Princeton 24 VIII 2005, [online] https://news.gallup.com/poll/18097/iraq-versus-vietnam-comparison-public-opinion.aspx, 14 VIII 2018. 


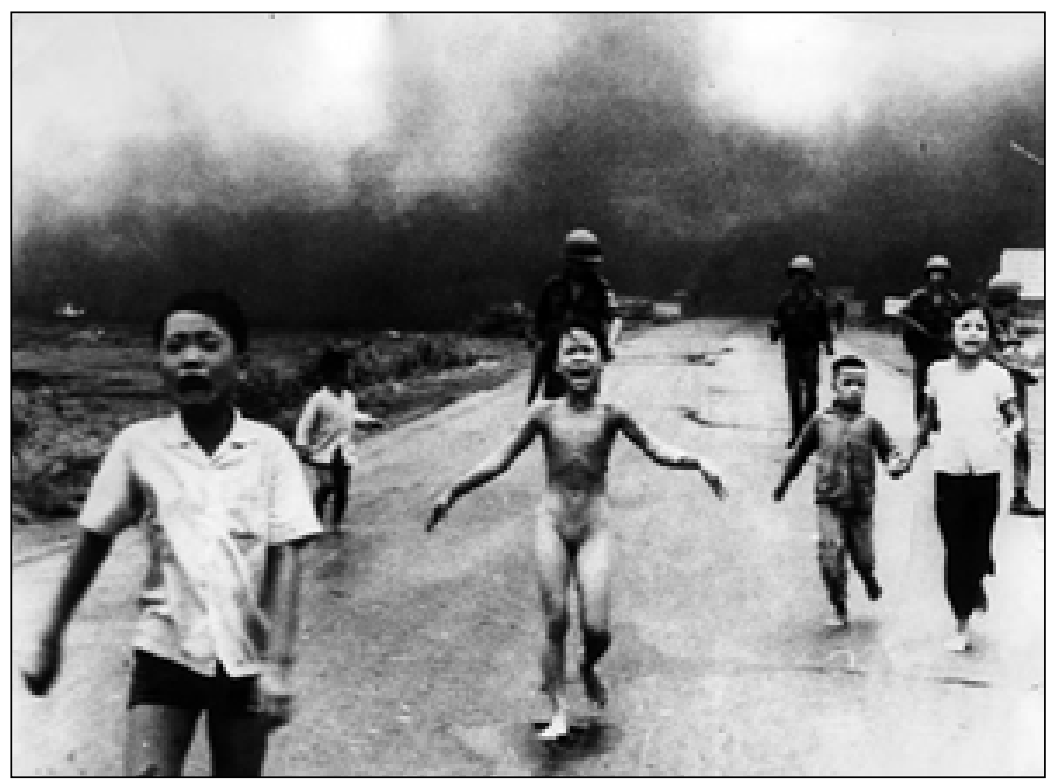

1. Zdjęcie poparzonej napalmem Kim Phuc zrobione w 1972 roku przez Nicka Uta zdobyło nagrodę Pulitzera i stało się symbolem amerykańskiej „brudnej wojny” w Wietnamie. (C) Huỳnh Công „Nick” Ut/Associated Press

Rys. 1. Sondaż opinii publicznej na temat interwencji amerykańskich wojsk w Wietnamie. Pytanie badawcze: W świetle rozwoju wydarzeń, odkąd włączyliśmy się do walk w Wietnamie, czy uważasz, że USA popełniły błąd, wysyłając wojska do Wietnamu? („In view of the developments since we entered the fighting in Vietnam, do you think the U.S. made a mistake sending troops to fight in Vietnam?”).

\section{Mistake to Send Troops to Vietnam?}

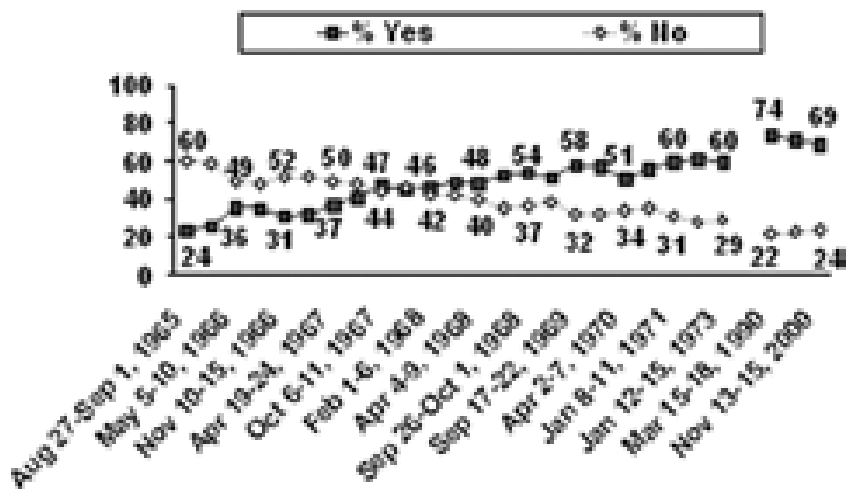

Źródło: http://www.gallup.com/poll/18097/iraq-versus-vietnam-comparison-public-opinion.aspx. 
Punktem zwrotnym w procesie zmiany nastawienia amerykańskiej opinii publicznej do wojny okazała się wspomniana już ofensywa Tet - pierwsza masowa, skoordynowana inwazja lądowa wojsk Północnego Wietnamu na południowowietnamskie miasta. Nie tylko Wietnam Południowy, ale i jego amerykańscy sojusznicy, mimo danych wywiadowczych jednoznacznie wskazujących na zbliżający się atak, zostali zaskoczeni rozmiarem i intensywnością działań wojennych. Rzeczywisty szok poznawczy czekał jednak amerykańskich obywateli, dotąd regularnie utwierdzanych w przekonaniu o nieuniknionej wygranej armii USA. Hurraoptymizm towarzyszący dotychczasowym przekazom wojennym, ukazującym amerykańskie ofiary jako rzecz pożałowania godną, lecz konieczną w szerszym planie światowego zwycięstwa wolności i demokracji, został nagle skonfrontowany z brutalną rzeczywistością krwawych wojennych starć, płonących domów i masowych grobów oraz wizją niekończącej się wojny, w której nie było miejsca ani na wzniosłe wartości, ani na głoszących je bohaterów. Obrazy oglądane na ekranach telewizorów dalekie były nie tylko od oficjalnie wygłaszanych przemówień, ale i od dominujących społecznych wyobrażeń wojennego zwycięstwa, kształtowanego dotąd poprzez cenzurowane przekazy z frontów wojny w Korei czy drugiej wojny światowej.

\section{OD POPARCIA DO POTĘPIENIA}

Początkowo wojna w Wietnamie cieszyła się stosunkowo wysokim poparciem amerykańskiego społeczeństwa. Imperatyw zatrzymania komunistycznego „efektu domina"13 w krajach azjatyckich, którego wystąpienie, według doktryny Eisenhowera, nieodwołalnie zmieniało status quo zimnej wojny na niekorzyść bloku demokratycznego i jednocześnie znacząco zwiększało ryzyko globalnego konfliktu, w pierwszych dekadach po drugiej wojnie światowej był dominującym elementem amerykańskiej polityki zagranicznej i stanowił element społecznego konsensusu. Wojna w Wietnamie wydawała się wówczas niską ceną za pokój na świecie - szczególnie w sytuacji przyspieszającego wyścigu zbrojeń i proliferacji broni jądrowej. Amerykańskie media - i społeczeństwo - bez zastrzeżeń i wątpliwości przyjęły początkowo oficjalną narrację o agresji strony północnowietnamskiej jako uzasadnieniu pełniejszego zaangażowania USA w konflikt wietnamski i przez pierwszych kilka lat obecności amerykańskich wojsk w Indochinach popierały politykę militarną swojego państwa jako wyraz dziejowej konieczności ${ }^{14}$.

Zmiana amerykańskiego nastawienia do wojny w Wietnamie odbywała się stopniowo, a poszczególne dramatyczne wydarzenia, które później urosły do rangi symboli, miały w ostatecznym rozrachunku bardziej efekt kumulatywnej ewolucji niż

13 W 1954 roku amerykański prezydent Dwight D. Eisenhower sformułował teorię efektu domina w odniesieniu do wpływu komunizmu na kraje azjatyckie. Koncepcja ta była później wykorzystywana do uzasadnienia interwencyjnego charakteru amerykańskiej polityki zagranicznej w rejonie Azji przez całe dekady.

14 D.C. Hallin, The „Uncensored War”..., r. 1-2. 
nagłej rewolucji. Wyrazisty przykład tej przemiany można znaleźć w historii Muhammada Alego, jednego z najwybitniejszych bokserów XX wieku. Kiedy w 1966 roku Muhammad Ali odmówił udziału w wojnie, został aresztowany i pozbawiony wszystkich tytułów, licencji bokserskiej oraz paszportu, co na kilka lat uniemożliwiło mu karierę sportową. Z ulubieńca Ameryki stał się wyrzutkiem, krytykowanym i wyszydzanym za swoje poglądy, religię i kolor skóry ${ }^{15}$. Jednak w miarę przemian nastrojów społecznych i wzrostu znaczenia antywojennej opozycji postawa Alego zaczęła być postrzegana jako wyrazisty symbol oporu wobec wojny i amerykańskiego establishmentu. Rozstrzygnięcie Sądu Najwyższego z 1971 roku, obalające poprzedni wyrok i oczyszczające Alego z zarzutów stanowiło dla wielu Amerykanów potwierdzenie niesprawiedliwości zarówno wietnamskiej wojny, jak i instytucji powszechnego poboru.

Wśród wielu powodów odwrócenia trendu poparcia dla wojny w Wietnamie, społecznych, psychologicznych, politycznych i ekonomicznych, jeden zasługuje na szczególną uwagę: po ofensywie Tet amerykańskie media zaczęły krytyczniej przyglądać się militarnemu zaangażowaniu USA w Indochinach, analizując istniejące podziały opinii nie tylko w społeczeństwie, ale i wśród elit polityczno-militarnych oraz biorących udział w walkach żołnierzy. Zniuansowany - i znacznie bardziej krwawy - obraz wietnamskiego konfliktu ułatwił zaistnienie większego pluralizmu poglądów w dyskursie publicznym. Szczególnie istotne w tym kontekście okazało się ujawnienie okoliczności masakry w Mỹ Lai, w czasie której amerykańscy żołnierze zabili z zimną krwią około pięciuset bezbronnych cywilów. Sprawa ta głęboko poruszyła amerykańskie społeczeństwo, w dużej mierze pozbawiając je złudzeń - zarówno tych dotyczących charakteru wojny w Wietnamie, której percepcja i oceny radykalnie różniły się od postrzegania drugiej wojny światowej, jak i tych na własny temat. Okazało się wówczas, że wojna potrafi wyzwolić najgorsze instynkty nawet $w$ tych najlepszych z najlepszych: wszyscy ci radośni i dobrze wychowani chłopcy z sąsiedztwa, troskliwi synowie i mężowie z ciężkim sercem wysyłani za morza, by wypełniać patriotyczny obowiązek i bronić własną krwią amerykańskich ideałów, okazali się zdolni do zbrodni. Skuteczne ukrywanie masakry przed obywatelami USA przez ich własny rząd oraz ambiwalentne traktowanie odpowiedzialnych za nią żołnierzy negatywnie odbiły się na poziomie społecznego zaufania do instytucji państwa oraz zrodziły zasadne, głośno zadawane pytania o istnienie innych potencjalnych tajemnic, których ujawnienie mogło być niewygodne dla polityków czy armii.

W 1969 roku przez stolicę USA w proteście przeciw amerykańskiemu zaangażowaniu w Wietnamie przemaszerowało 250 tys. ludzi. Rok później przeciwnicy wojny podłożyli bombę na uniwersytecie Wisconsin-Madison, a wielodniowy, stopniowo przybierający na sile i gwałtowności protest studentów na kampusie Kent State University został krwawo stłumiony przez oddziały amerykańskiej Gwardii Narodowej. Rosnący sprzeciw wobec wojny ujawnił głębokie podziały społeczne, przebiegające

15 K. Calamur, Muhammad Ali and Vietnam, „The Atlantic” 2016, 4 IV, [online] https://www. theatlantic.com/news/archive/2016/06/muhammad-ali-vietnam/485717/, 31 X 2019. 
wzdłuż linii demograficznych: wykształcenia, wieku, zamożności, przekonań politycznych i religijnych oraz rasy. Wojna w Wietnamie z zamorskiego, niezbyt istotnego konfliktu na niewielką skalę, interesującego głównie militarnych strategów oraz badaczy polityki zagranicznej, przekształciła się w wydarzenie epokowe, w niezwykle istotny sposób transformujące i definiujące amerykańską tożsamość.

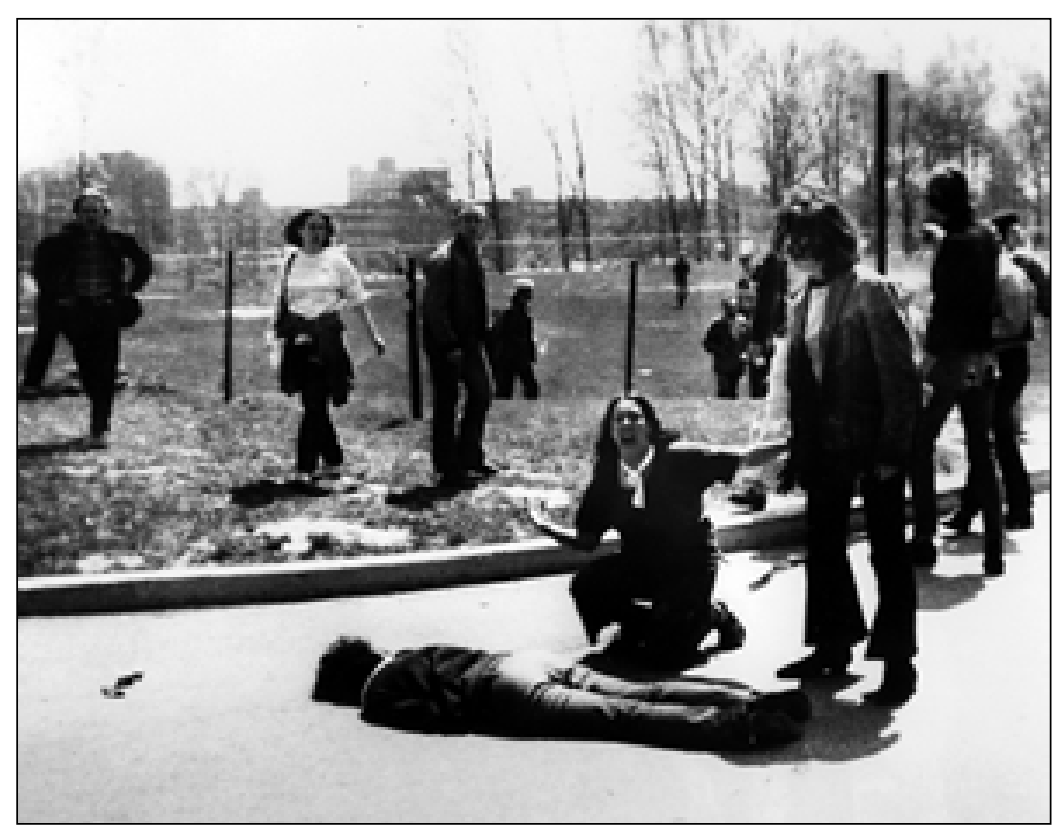

2. Zdjęcie efektów masakry w Kent State University zrobione przez Johna Paula Filo zdobyło w 1971 roku nagrodę Pulitzera $\odot$ John Paul Filo

Kluczowym elementem tego procesu okazała się sfera kultury. Współczesny obraz amerykańskiego zaangażowania militarnego w Wietnamie składa się z setek tysięcy artefaktów kulturowych - od osobistych świadectw, fotografii, pamiątek materialnych, opublikowanych biografii i obszernie udokumentowanych dzieł naukowych oraz filmów dokumentalnych, poprzez zbeletryzowane wspomnienia, filmowe narracje i wielopoziomowe artystyczne metafory, społeczne tabu i podzielane w obrębie wspólnoty wyobrażenia czy niewypowiedziane założenia na temat rzeczywistości, aż po określenia pochodzące z żołnierskiego slangu, które zakorzeniły się w języku potocznym, czy wreszcie rozmaite dzieła nawiązujące do wietnamskiego doświadczenia, pojawiające się w amerykańskiej kulturze do dziś. Już w 1984 roku istniało około dwustu książek poświęconych tematyce wojny w Wietnamie ${ }^{16}$, zaś większość najistotniejszych dzieł fikcji

16 M. Kakutani, Novelists and Vietnam: The War Goes On, „The New York Times” 1984, 15 IV, [online] https://www.nytimes.com/1984/04/15/books/novelists-and-vietnam-the-war-goes-on.html, 15 VIII 2018. 
literackiej i filmowej zaczęła powstawać dopiero po 1975 roku, kiedy większość twórców uzyskała do tamtych wydarzeń konieczny dystans.

\section{KONKURENCYJNE WIZJE WOJNY}

Jeszcze w trakcie trwania wojny amerykańska kultura stała się miejscem wewnętrznego starcia dwóch obrazów wietnamskiego konfliktu i uwikłanych weń żołnierzy, przedstawianych zazwyczaj w skrajnych rolach: katów albo ofiar. Stynne określenie „babykillers”, czyli zabójcy dzieci, towarzyszyło umundurowanym weteranom od 1970 roku, kiedy ruch antywojenny wykorzystał jako plakat propagandowy zdjęcie Ronalda L. Haeberle, przedstawiające ofiary masakry w Mỹ Lai, z nadrukowanym pytaniem Mike’a Wallace’a z CBS News i odpowiedzią Paula Meadlo, uczestnika tamtych wydarzeń. Jednak bezpośrednie przypisanie winy za masakrę zaangażowanym w nią żołnierzom okazało się bronią obosieczną: antywojenni aktywiści nie tylko nakreślili nowe linie podziałów społecznych, między cywilami a wojskiem, ale również zagubili w tym procesie szerszą perspektywę spojrzenia na wojnę w Wietnamie jako na efekt działania politycznego amerykańskich instytucji. Złożone procesy stygmatyzacji, których wspomniane zdjęcie (il. 3) jest jedynie przykładem, znacząco wpłynęły na społeczne postrzeganie weteranów wojny w Wietnamie. Ich obraz w społecznym odbiorze był w owym czasie zasadniczo odmienny od wizerunku weteranów wcześniejszych wojen, drugiej wojny światowej czy wojny w Korei, które przez większość amerykańskiego społeczeństwa uznawane były za „sprawiedliwe”. Dla weteranów wojny w Wietnamie nie organizowano parad zwycięstwa, trudna sytuacja ekonomiczna kraju negatywnie odbijała się na poziomie instytucjonalnej opieki nad rannymi i potrzebującymi, a wielu powracających $\mathrm{z}$ frontu żołnierzy do dziś wspomina wrogość i niechęć społeczeństwa, z którą zetknęli się po powrocie do domu ${ }^{17}$.

Z drugiej zaś strony wojna w Wietnamie coraz częściej przedstawiana była jako źródło chaosu i szaleństwa, miejsce, które nieodwołalnie zmienia wysyłanych weń ludzi i z którego nie da się powrócić całkiem normalnym - z którego nikt tak napraw$\mathrm{dę} \mathrm{w}$ pełni nie wraca ${ }^{18}$. Mimo że filmografia postwietnamska pełna jest obrazów niezrozumiałego chaosu wojny, by przytoczyć tu tylko najbardziej znane tytuły, takie jak

17 Do dziś nie ustają kontrowersje dotyczące kwestii plucia na powracających weteranów; w 1989 roku Bob Greene, dziennikarz „Chicago Tribune”, opublikował kolekcję listów od weteranów, w których opisywali sytuacje otwartej wrogości, z jaką stykali się w kraju; niemal dekadę później Jerry Lembcke wydał polemikę z książką Greene’a, uznając plucie za mit, a źródła Greene’a za niesprawdzone. Jednak nie ulega wątpliwości, że wzrastające antagonizmy społeczne i agresja obu stron konfliktu politycznego w USA odbijały się na weteranach, przyczyniając się do powstania atmosfery wrogości i niechęci wobec powracających żołnierzy. B. Greene, Homecoming: When the Soldiers Returned from Vietnam, New York 1989; J. Lembcke, The Spitting Image: Myth, Memory and the Legacy of Vietnam, New York 1998; G. Kulik, „War Stories”: False Atrocity Tales, Swift Boaters and Winter Soldiers - What Really Happened in Vietnam, Virginia 2009.

18 Według różnych szacunków między 70 tys. a 300 tys. amerykańskich weteranów wojny w Wietnamie popełniło samobójstwo. 
Eowca jeleni Michaela Cimino (1978), Pluton Oliviera Stone’a (1986) czy Full Metal Jacket Stanleya Kubricka (1987), kluczowym z tej perspektywy dziełem okazał się obraz Czas Apokalipsy w reżyserii Francisa Forda Coppoli (1979), będący swobodną ekranizacją Jądra ciemności Josepha Conrada, osadzoną w realiach wietnamskiego konfliktu. Wybitne dzieło Coppoli, na tle niezwykle realistycznie i absurdalnie zarazem ukazanej rzeczywistości wietnamskiej wojny przedstawiające uniwersalną przypowieść o ludzkim złu, mogącym kryć się w każdym z nas, okazało się idealnym obrazem wojny dla znacznej części amerykańskiego społeczeństwa. Zmęczona, zagubiona, niepewna twarz grającego główną rolę Martina Sheena stała się symbolem wietnamskich weteranów w podobny sposób, jak twarz Larry'ego Wayne’a Chaffina ze zdjęcia zrobionego w 1965 roku przez Horsta Faasa była na początku wojny symbolem amerykańskich żołnierzy walczących w Wietnamie.

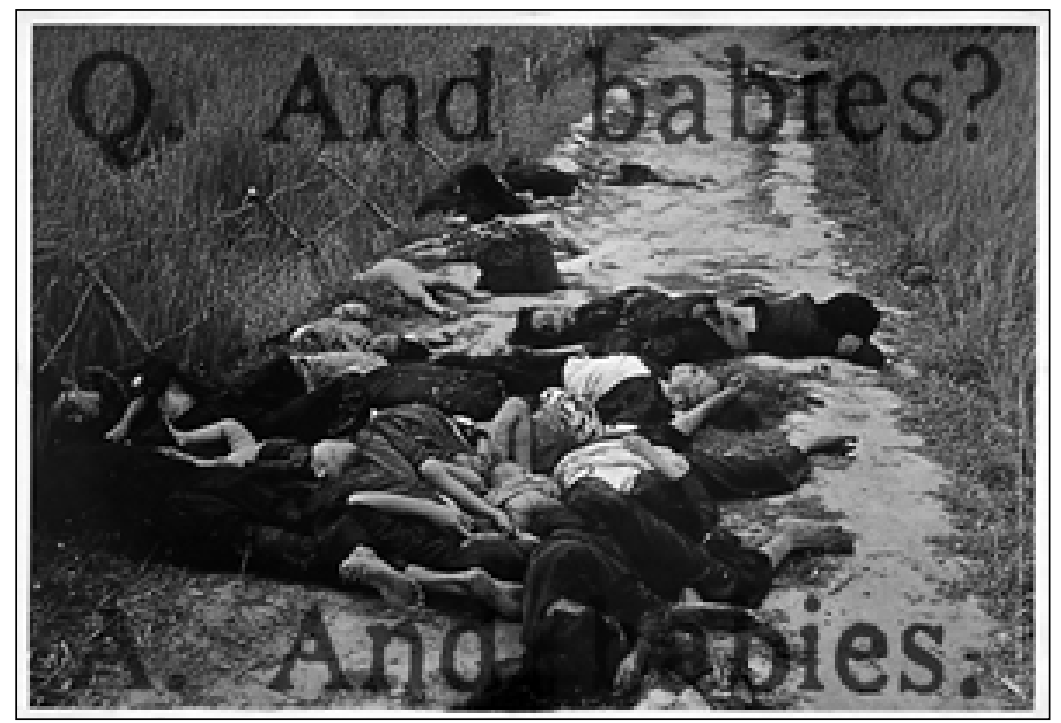

3. Irving Petlin, Jon Hendricks, Frazer Dougherty, „Q. And babies? A. And babies”. Cytat z wywiadu z Paulem Meadlo naniesiony na fotografię Ronalda L. Haeberle'a, 1970. Plakat z kolekcji MoMa

Zmiany w ikonografii obrazu żołnierzy wietnamskiej wojny są nie do przeoczenia. W czasie tych kilkunastu lat, dzielących zdjęcie Faasa i film Coppoli, znikła gdzieś radosna niewinność spojrzenia, zastąpiona nieusuwalnym zmęczeniem i przygniatającym, niewypowiedzianym doświadczeniem koszmaru wojny. Optymizm i obietnica zwycięstwa, pomimo wszelkich przeszkód, ustąpiły miejsca gorzkiej świadomości uwikłania w konflikt, w którym nie ma - i nie może być - zwycięzców. Jednak w obrazie Coppoli grany przez Sheena Willard, w przeciwieństwie do swego filmowego antagonisty, opętanego szaleństwem i boską ambicją Kurtza, wciąż jeszcze pozostaje człowiekiem: ułomnym, błądzącym i pełnym wątpliwości, lecz jednak ostatecznie opowiadającym się po stronie społeczeństwa i panujących w nim zasad i reguł, 
pomimo, a może właśnie ze względu na wszystkie jego błędy i niedoskonałości. Wojna w ujęciu Coppoli niszczy wszystkich - choć niejednakowo. I choć cena, jaką każdy musi zapłacić za poznanie samego siebie, nie jest dla wszystkich taka sama, w ostatecznym rozrachunku każdy dotknięty chaosem wojny prędzej czy później musi ją zapłacić.

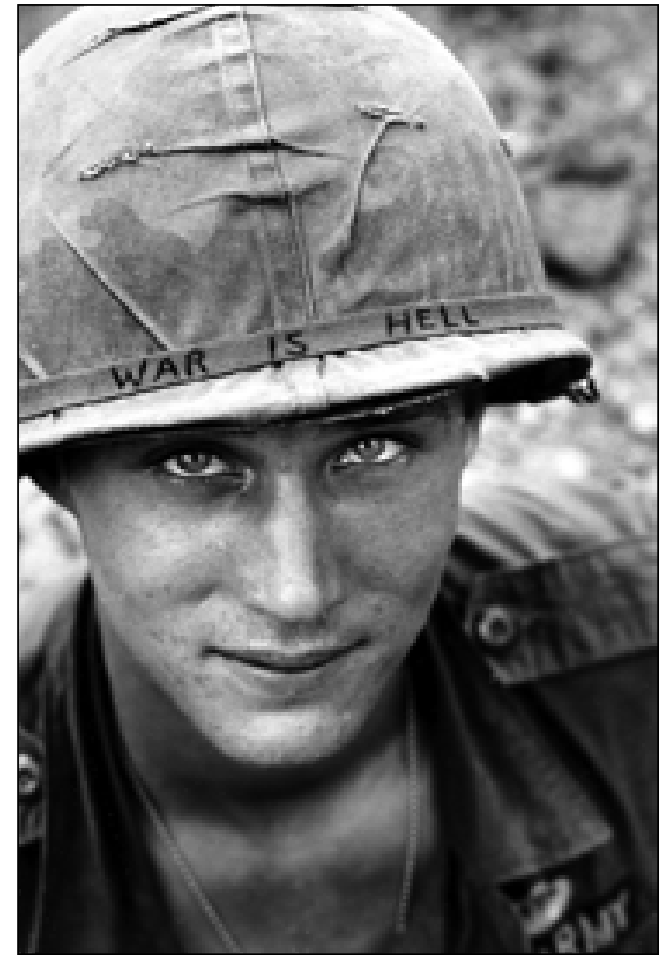

4. „War is hell”. Larry Wayne Chaffin na zdjęciu Horsta Faasa, 1965

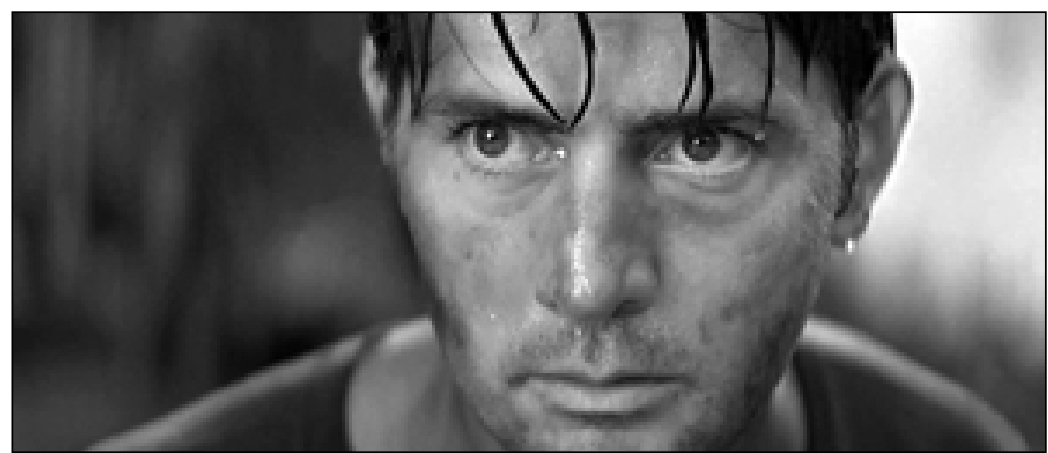

5. Martin Sheen jako Benjamin Willard w Czasie Apokalipsy F.F. Coppoli (1979). 


\section{KONKURENCYJNE WIZJE PAMIĘCI}

Skomplikowany, niejednoznaczny obraz wojny w Wietnamie, jaki wytworzył się $\mathrm{w}$ świadomości amerykańskiego społeczeństwa, nie ułatwiał samym weteranom odnalezienia się w podzielonej rzeczywistości. Traktowani jak kaci lub jak ofiary, nierzadko jak kaci i ofiary jednocześnie, stanowili żywe, natrętne przypomnienie winy i wstydu, o których większość obywateli USA chciałaby jak najszybciej zapomnieć. Poczucie odrębności własnej sytuacji, świadomość zarazem unikalności indywidualnych przeżyć, jak i paradoksalnie krzepiącej powtarzalności ogólnych zrębów doświadczeń w obrębie całego pokolenia podobnie dotkniętych wojną jednostek były katalizatorami procesu stopniowego pojawiania się w sferze publicznej rozmaitych stowarzyszeń i grup wsparcia. Przykładem takiego wspólnego, zaplanowanego działania w sferze kultury i świadomości amerykańskiego społeczeństwa jest historia pomnika poległych i zaginionych w czasie wojny w Wietnamie.

Idea budowy pomnika pojawiła się pod koniec lat $70 . \mathrm{XX}$ wieku wśród samych weteranów, którzy w 1979 roku utworzyli w tym celu organizację The Vietnam Veterans Memorial Fund, Inc. (VVMF). W efekcie ich działań, wspartych przez kongresmenów, w 1980 roku prezydent Jimmy Carter podpisał akt legislacyjny, udostępniając pod budowę pomnika teren w Ogrodach Konstytucji w Waszyngtonie. Prosta, niemal abstrakcyjna forma muru z czarnego granitu symbolicznie rozpościera się w dwóch kierunkach: pomników Jerzego Waszyngtona i Abrahama Lincolna. Na wypolerowanej powierzchni wykuto 58272 imiona i nazwiska - dane wszystkich żołnierzy, którzy zginęli lub zaginęli w czasie walk w Wietnamie ${ }^{19}$. W 1984 roku ukończony monument wraz z otaczającymi go terenami zielonymi oficjalnie został uznany za park narodowy.

Oficjalna akceptacja idei pomnika umożliwiła weteranom jako grupie otwarcie publicznej debaty dotyczącej amerykańskiego udziału w konflikcie, w szczególności zaś roli i odpowiedzialności nie tylko walczących w Wietnamie żołnierzy, ale i tych Amerykanów, którzy pozostali w domu. Zakres i waga uczestnictwa weteranów jako grupy interesu w amerykańskim życiu publicznym zwiększyły się również w wyniku zmian w naukowym postrzeganiu traumy wojennej - oficjalne uznanie Post-traumatic Stress Disorder (PTSD) za jednostkę chorobową było bowiem de facto rezultatem złożonych procesów negocjacji znaczeń i - stosując język Habermasa - ocen zróżnicowanych roszczeń do ważności ${ }^{20}$ wciąż powiększającego się zbioru wypowiedzi weteranów i ich terapeutów ${ }^{21}$. Postrzeganie traumy wojennej stopniowo ulegało zmianie. Trauma

19 The Vietnam Veterans Memorial, [online] http://www.thewall-usa.com/information.asp, 17 VIII 2018.

20 J. Habermas, Teoria dziatania komunikacyjnego, t. I-II, przeł. A.M. Kaniowski, Warszawa 1999, 2002.

21 Zob. Stress Disorders among Vietnam Veterans: Theory, Research and Treatment, red. C.R. Figley, New York 1978; J.A. Boscarino, J.J. Boscarino, Conceptualization of PTSD from the Vietnam War to Current Conflicts and Beyond, „International Journal of Emergency Mental Health and Human Resilience” 2015, vol. 17, nr 3, s. 661-663. 
ta, widziana początkowo jako wstydliwy, indywidualny problem, którego pojawienie się miało obnażać słabość psychologicznej konstrukcji jednostki poddanej stresującym wydarzeniom, powoli zaczęła być uznawana za naturalną odpowiedź organizmu na stresujace wydarzenie lub sytuacje wyjątkowo przerazajacej lub katastroficznej natu$r y^{22}$. Przemiany świadomości społecznej w odniesieniu do problematyki traumy psychicznej są długotrwałym i niezwykle skomplikowanym procesem. Mimo że wzmianki o traumie bojowej pojawiały się w kulturze zachodniej od czasów antycznych ${ }^{23}$, w pooświeceniowej Europie i Ameryce psychiczne problemy żołnierzy biorących udział w walkach przez długi czas uznawane były za przykłady jednostkowego nieprzystosowania psychicznego, brak męstwa czy wręcz tchórzostwo, a nawet próby symulowania chorób w celu uniknięcia dalszej służby ${ }^{24}$. Zmiana tego nastawienia i oficjalne uznanie PTSD za formę zaburzenia psychicznego umożliwity daleko idące przemiany amerykańskiej świadomości społecznej: uświadomienie sobie zbiorowej odpowiedzialności za udział w wojnie i przynajmniej częściowe zdjęcie odium katów z biorących w niej udział żołnierzy ${ }^{25}$.

\section{ZAKOŃCZENIE}

Indywidualne przypadki traumy wojennej, zebrane i przekształcone przy użyciu mediów kultury w oddzielone od ich „nosicieli” artefakty kulturowe, stały się podstawą społecznie podzielanej sfery doświadczeń i wspomnień, a co za tym idzie - istotnym elementem pamięci zbiorowej amerykańskiego społeczeństwa. Wojna w Wietnamie, zarówno w postaci zintersubiektywizowanego doświadczenia wojennej traumy, jak i zapośredniczonej przez media wspólnoty przeżyć społeczności, jest dziś nieusuwalną częścią amerykańskiej tożsamości. Proces strukturyzacji znaczenia przyjętej w obręb wspólnego doświadczenia powietnamskiej traumy społecznej trwa jednak nadal, a wciąż toczone zbiorowe negocjacje i zażarte debaty dotyczące historycznego i współczesnego znaczenia wietnamskiego konfliktu, jak choćby przy okazji upamiętnienia

22 The ICD-10 Classification of Mental and Behavioural Disorders, World Health Organization, 2016, [online] http://apps.who.int/classifications/icd10/browse/2016/en\#/F40-F48, 17 VIII 2018.

23 Zob. J. Shay, Achilles in Vietnam. Combat Trauma and the Undoing of Character, New York 2003; W. Abdul-Hamid, J.H. Hughes, Nothing new under the sun: post-traumatic stress disorders in the ancient world, „Early Science and Medicine” 2014, vol. 19, nr 6, s. 549-557.

24 Zob. G.L. Mosse, Shell Shock as a Social Disease, „Journal of Contemporary History” 2000, vol. 35, $\mathrm{nr}$ 1, s. 101-108; L. Bibbings, Images of Manliness: the Portrayal of Soldiers and Conscientious Objectors in the Great War, „Social \& Legal Studies” 2003, nr 12, s. 335-358; S. Wessely, Twentieth-century Theories on Combat Motivation and Breakdown, "Journal of Contemporary History” 2006, vol. 41, nr 2, s. 269-286.

25 Rosnąca świadomość istnienia oraz przyczyn i skutków PTSD przyczyniły się do uruchomienia przez Kongres w 1979 roku programu pomocy weteranom Vietnam Veterans Readjustment Counseling. C.R. Figley, J.A. Boscarino, The Traumatology of Life, „The Journal of Nervous and Mental Disease” 2012, vol. 200, nr 12, s. 1113-1120. 
50. rocznicy rozpoczęcia wojny w Wietnamie ${ }^{26}$, dobitnie ukazują wagę tego wydarzenia dla amerykańskiej tożsamości zbiorowej. Oficjalne próby uwznioślenia tego konfliktu, przedstawienia go jako serii bohaterskich wyczynów, amerykańskiego triumfu militarnego czy nawet wojny ideologicznych racji spotykają się ze zdecydowanym oporem tych, którzy wciąż jeszcze pamiętają tę wojnę - czy to z własnego, czy też zapośredniczonego doświadczenia. Dlatego też pamięć - płynna, zmienna, podlegająca negocjacjom, występująca zarówno w formie społecznej traumy, przekazywanych z pokolenia na pokolenie intymnych wspomnień, jak i szeroko znanych dzieł kultury - jest nie tylko niezbędnym elementem wspólnotowej tożsamości, ale i szansą na uniknięcie popełniania wciąż tych samych błędów.

\section{BIBLIOGRAFIA}

Abdul-Hamid W., Hughes J.H., Nothing new under the sun: post-traumatic stress disorders in the ancient world, „Early Science and Medicine” 2014, vol. 19, nr 6, https://doi.org/ 10.1163/15733823-00196p02.

Berger J., Which Prosthetic? Mass media, Narrative, Empathy and Progressive Politics, „Rethinking History" 2007, vol. 11, nr 4, https://doi.org/10.1080/13642520701652152.

Bibbings L., Images of Manliness: the Portrayal of Soldiers and Conscientious Objectors in the Great War, „Social \& Legal Studies” 2003, vol. 12, https://doi.org/10.1177/09646639030 123003.

Boscarino J.A., Boscarino J.J., Conceptualization of PTSD from the Vietnam War to Current Conflicts and Beyond, „International Journal of Emergency Mental Health and Human Resilience" 2015, vol. 17, nr 3, https://doi.org/10.4172/1522-4821.1000278.

Davidson P.B., Vietnam at War. The History 1946-1975, Oxford 1991.

Figley C.R., Boscarino J.A., The Traumatology of Life, „The Journal of Nervous and Mental Disease" 2012, vol. 200, nr 12, https://doi.org/10.1097/NMD.0b013e318275d559.

Greene B., Homecoming: When the Soldiers Returned from Vietnam, New York 1989.

Gruszczyk A., Czarne światto. Analiza zjawiska powojennej traumy spotecznej w kulturze Stanów Zjednoczonych Ameryki. Kraków 2017.

Habermas J., Teoria dziatania komunikacyjnego, t. I-II, przeł. A.M. Kaniowski, Warszawa 1999, 2002.

Halbwachs M., Spoteczne ramy pamięci, przeł. M. Król, Warszawa 2008.

Hallin D.C., The „Uncensored War”: The Media and Vietnam, Berkeley-Los Angeles 1989.

Hirsch M., Family Frames. Photography, Narratives and Postmemory, Cambridge 1997.

Hirsch M., The Generation of Postmemory, „Poetics Today” 2008, vol. 29, nr 1, https://doi. org/10.1215/03335372-2007-019.

26 S.G. Stolberg, Paying Respects, Pentagon Revives Vietnam, and War Over Truth, „The New York Times” 2014, 9 X, [online] https://www.nytimes.com/2014/10/10/us/pentagons-web-timeline-bringsback-vietnam-and-protesters-.html hp\&action $=$ click\&pgtype $=$ Homepage\&version $=$ HpSum \&module=second-column-region\&region=top-news\&WT.nav=top-news, 20 VIII 2018. 
Kulik G., „War Stories”: False Atrocity Tales, Swift Boaters and Winter Soldiers - What Really Happened in Vietnam, Virginia 2009.

Landsberg A., Prosthetic Memory: The Transformation of American Remembrance in the Age of Mass Culture, New York 2004.

Lembcke J., The Spitting Image: Myth, Memory and the Legacy of Vietnam, New York 1998.

Mosse G.L., Shell Shock as a Social Disease, „Journal of Contemporary History” 2000, vol. 35, nr 1, https://doi.org/10.1177/002200940003500109.

Shay J., Achilles in Vietnam. Combat Trauma and the Undoing of Character, New York 2003. Smelser N., Psychological and Cultural Trauma, [w:] J.C. Alexander, R. Eyerman, B. Giesen, N.J. Smelser, P. Sztompka, Cultural Trauma and Collective Identity, Berkeley 2004, https:// doi.org/10.1525/california/9780520235946.003.0002.

Stress Disorders among Vietnam Veterans: Theory, Research and Treatment, red. C.R. Figley, New York 1978.

Wessely S., Twentieth-century Theories on Combat Motivation and Breakdown, „Journal of Contemporary History" 2006, vol. 41, nr 2, https://doi.org/10.1177/0022009406062067.

\section{Filmy}

Cimino M., The Deer Hunter / Eowca jeleni, 1978.

Coppola F.F., Apocalypse Now! / Czas Apokalipsy, 1979.

Kubrick S., Full Metal Jacket / Full Metal Jacket, 1987.

Stone O., Platoon / Pluton, 1986.

\section{Źródła internetowe}

Calamur K., Muhammad Ali and Vietnam, „The Atlantic” 2016, 4 IV, [online] https://www. theatlantic.com/news/archive/2016/06/muhammad-ali-vietnam/485717/, 31.10.2019.

DeBruyne N.F., American War and Military Operations. Casualties: Lists and Statistics, Congressional Research Service, 2017, [online] https://fas.org/sgp/crs/natsec/RL32492.pdf, 13 VIII 2018.

Kakutani M., Novelists and Vietnam: The War Goes On, „The New York Times” 1984, 15 IV, [online] https://www.nytimes.com/1984/04/15/books/novelists-and-vietnam-the-war-goeson.html, 15 VIII 2018.

Newport F., Carroll J., Iraq Versus Vietnam: A Comparison of Public Opinion, Gallup News Service, Princeton 24 VIII 2005, [online] https://news.gallup.com/poll/18097/iraq-versus-vietnam-comparison-public-opinion.aspx, 14 VIII 2018.

Stolberg S.G., Paying Respects, Pentagon Revives Vietnam, and War Over Truth, „The New York Times" 2014, 9 X, [online] https://www.nytimes.com/2014/10/10/us/pentagons-webtimeline-brings-back-vietnam-and-protesters-.html?hp\&action=click\&pgtype=Homepag e\&version $=H$ pSum \& module $=$ second - column-region\&region $=$ top-news $\& W T$.nav $=$ topnews, 20 VIII 2018.

The ICD-10 Classification of Mental and Behavioural Disorders, World Health Organization, 2016, [online] http://apps.who.int/classifications/icd10/browse/2016/en\#/F40-F48, 17 VIII 2018. 
The Vietnam Veterans Memorial, [online] http://www.thewall-usa.com/information.asp, 17 VIII 2018.

Tybjerg C., Refusing the Reality Pill: A Film Studies Perspective on Prosthetic Memory, Kosmorama, 10 III 2016, [online] https://www.kosmorama.org/en/kosmorama/artikler/refusingreality-pill-film-studies-perspective-prosthetic-memory, 31 X 2019.

http://100photos.time.com/photos/john-paul-filo-kent-state-shootings, 31 X 2019.

https://rarehistoricalphotos.com/soldier-war-is-hell-vietnam-1965/, 16 VIII 2018.

https://www.imdb.com/title/tt0078788/mediaviewer/rm3155625216, 27 VIII 2018.

https://www.moma.org/collection/works/7272, 15 VIII 2018.

http://www.thewall-usa.com/names.asp, 13 VIII 2018.

Dr Aleksandra GRUSZCZYK - absolwentka Uniwersytetu Jagiellońskiego. Autorka książek: Bezpieczeństwo za cenę wolności. Analiza wybranych aspektów zachowań wyborczych Polaków po roku 1989; Czarne światto. Analiza zjawiska powojennej traumy spotecznej w kulturze Stanów Zjednoczonych Ameryki, a także wielu artykułów poświęconych m.in. zagadnieniom powojennej traumy społecznej, moralności i przemocy, oraz dylematom wolności i bezpieczeństwa. 